\title{
Steroid Hormone Receptor ERR2
}

National Cancer Institute

\section{Source}

National Cancer Institute. Steroid Hormone Receptor ERR2. NCI Thesaurus. Code C139919.

Steroid hormone receptor ERR2 (508 aa, $\sim 56 \mathrm{kDa}$ ) is encoded by the human ESRRB gene.

This protein plays a role in inner ear development, stem cell maintenance and rod cell survival. 